Fifteen lectures were given during Course 17 on topics of radiofrequency spectroscopy. They dealt with masers, atomic beams, magnetic resonance and the measurement of time. The lecturers included K. Shimoda (University of Tokyo), C. H. Townes (Columbia University), J. Brossel and A. Kastler (Ecole Normale Supérieure, Paris), A. Abragam (Centre d'Etudes Nucléaires, Saclay) and members of the Lawrence Radiation Laboratory, Berkeley, California. Since 1960 when the course was held there have been considerable technical developments in most of the branches discussed, but the basic principles and fundamental thøory remain practically unaltered. Hence, the clear expositions given in the proceedings of Course 17 still represent a valuable set of introductory monographs on their subjects, to be supplemented by research articles publisbed during the past three years. The introduction to the Proceedings is by the director of the course and is in Italian. The lectures are in English or French.

It is to be emphasized that the students attending the aforementioned courses were expected to be reasonably well acquainted with the subjects under discussion and to be trained physicists and mathematicians. The Proceedings will, therefore, be of use only as reference monographs or for postgraduate reading and instruction. The libraries of universities and physical research establishments can ill afford to omit the series from their shelves, but the purchase by individuals is bound to bo extremely limited. It is to be hoped that the Proceedings of the 1961 and 1962 courses will be published soon and that the interval between a course and the publication of its Proceedings will be reduced considerably.

S. Wenntroub

\section{BIOCHEMISTRY OF CANCER}

\section{An Introduction to the Biochemistry of the Cancer} Cell

By Harris Busch. Pp. xiv +424 . (New York: Academic Press, Inc.; London: Academic Press, Inc. (London), Ltd., 1962.) 96s. 6d.

SINCE Greenstein wrote his now classical Biochemistry of $S$ Cancer ${ }^{1}$ and since his all-too-early death, nothing like Busch's book has been published. Under the modest title of An Introduction, it treats the important subject-matter, important for a great number of people even outside the cancer research fraternity, in a different, individualistic and obviously up-to-date way. The first and very likely lasting impression is that it is a worthy successor to the work of Greenstein, who on a number of occasions is quoted by Busch. However, although only eight years have passed since the second and last edition of Greenstein's book was published, the differences in the funda. mental approaches between the two publications are considerable. It is in fact interesting to read the two books side by side, if one can spare the time for such leisurely occupation these days, and compare the main theme of their essays. It is natural that any writer of scientific reviews or text-books is being guided to a large extent by his own research interests. Thus one finds in 'Greenstein' enzyme patterns in the foreground, and in 'Busch' the more recently developed problems of nucleic acid (DNA. and RNA) control, protein biosynthesis and immunological properties, showing up the changing fashions inside a decade.

On the other hand, there are many points of contact between predecessor and successor such as their tendency to look for cancer-specific constituents. During Greenstein's last years of undiminished activity he discussed in lectures ${ }^{2}$ the existence of potentially toxic substances produced by cancers and influencing the levels of catalase in the liver of tumour-bearing animals; Busch discusses the toxohormone of Japanese workers ${ }^{3}$, together with other abnormal products found under neoplastic conditions, such as abnormal serum proteins in plasma- cytoma and abnormal mucoproteins. Greenstein, still very much under the impact of the Warburg concept ${ }^{4}$ of impaired respiration and pronounced aerobic glycolysis of tumours, is naturally less critical of the situation than Busch with Aisenberg's ${ }^{5}$ balanced review of the whole problem of energy producing metabolism and his own work behind him.

Where one is inclined to stick with Greenstein and take some stand against Busch is the over-emphasis of the latter on the cancer cell (see title), as if such a cell could exist in biological systems without an environment. Greenstein, though some of his results may have slightly aged, dedicates almost eighty pages to the chemistry of the tumourbearing host, and Busch commits himself to this cancer cell independence idea by calling his last chapter, "The Cancer Cell as a Parasite". Would the clinicians agree with this ?

It was said before that this book is a good one; it is well produced and has an excellent collection of references. In the not too distant future scientists and medici, coming into the library, will ask where is the 'Busch', instead of asking where is the 'Greenstein'.

F. Berger

1 Greenstein, J. P., Biochemistry of Cancer (Academic Press Inc., Publishers, New York. First edition 1947, second edition 1954).

2 Greenstein, J. P., "Cancer and Biochemistry", Jap. Biochem. Soc., October, 1956.

${ }^{3}$ Nakahara, W., and Fukuoka, F., Toxohormone (C. C. Thomas, Springfleld, III., 1961).

4 Warburg, O., The Metabolism of Tumours (Constable, London, 1930).

'Aisenberg, A. C., The Glycolysis and Respiration of Tumours (Academic Press Inc., Publishers, New York, 1961).

\section{INTERNATIONAL CO-OPERATION AND ANIMAL WELFARE}

FAO-WHO-OIE Animal Health Yearbook, 1962 Pp. viii + 399. (Rome: Food and Agriculture Organization of the United Nations, 1963.) 15s.; 3 dollars; $10.50 \mathrm{Fr}$. francs.

THE Year Book issued jointly by the Food and Agriculture Organization of the United Nations, the World Health Organization, and the International Epizootics Office, Paris, is a factual production for use somewhat on the lines of a railway time-table, essential for reference, but with a strictly limited function. It is a large book,

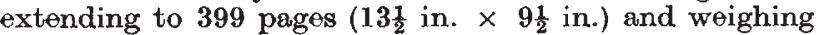
$3 \mathrm{lb}$.

243 pages cover the disease position in each country, set out according to a standard plan and arranged geographically according to continents. Diseases of bees and diseases of fish each occupy two pages. The sections on livestock populations, on the number of veterinarians and on diseases not listed in the earlier part of the book cover 16 pages. There is an article on "Some Major Changes in the Livestock Disease Position in 1961". Maps and data are given of the incidence and distribution of foot-and-mouth disease and vesicular stomatitis. Additional information is given about diseases in South Africa, the Philippines and Japan. A brief article deals with 'red tide' in South Africa during 1958, caused by a dinoflagellate, Gonyaulux polygramma in the red plankton, as a result of which there is, on occasion, serious local mortality in sea fish. It occurs at infrequent intervals in various parts of the world. Economic losses caused by animal diseases in the different countries are discussed in a brief article, followed by data for each country (90 pages).

The text and tables are set out completely in sequence, in English, French and Spanish. The information given is not only unobtainable elsewhere in a single book, but also the bulk of it is unobtainable elsewhere. Particularly important is the information given about the emergent countries. The international bodies responsible for this publication are concerned with animal health and disease matters everywhere, and on their behalf experts visit or 